\title{
Inheritance and Development of Traditional Art Spirit in Contemporary Art Education
}

\author{
Liqin Zheng \\ Nanjing Xiaozhuang University, Jiangsu, China, 210019
}

Keywords: Preschool education; Art teaching; Traditional art; Inheritance; Development; Innovation.

\begin{abstract}
Nowadays, art education has entered a diversified era. Modern advanced and rich traditional art ideas are integrated into each other. In the art teaching of preschool education, modern and traditional cultural elements have been integrated into the teaching content. Many teachers and students have a brand-new understanding of the standards of art teaching quality. The cultivation of students 'comprehensive art ability is not only the cultivation of traditional art technical ability, but also the cultivation of the inheritance, development and innovation ability of traditional art. At the same time, the teaching difficulty of teachers is increasing. Starting from the teaching of traditional fine arts, this paper explores the innovative ideas and inheritance ideas based on traditional fine arts teaching. Innovation of traditional fine arts is not only a subject to meet the current era, but also an effective guarantee to train all-round high-quality talents for the modern society. Extending to today, traditional art has certain practical significance for people of different ages and has far-reaching influence on students of preschool education. Therefore, in order to realize the innovation and development of traditional art in art teaching in preschool education and keep pace with the times, we must inherit and develop art culture, weed out the old and bring forth the new, and create a new trend of traditional art.
\end{abstract}

\section{Introduction}

Influenced by globalization, various advanced modern teaching equipment are constantly emerging. At the same time, some avant-garde ideas have entered the campus with a brand-new face. The teaching methods and contents of art education in our country have also undergone great changes, which provides conditions for enriching the teaching resources of art education in our country. The continuous deepening of education reform has promoted the great progress and development of art education and teaching in China, enriched art education ideas, and made art education develop in a pluralistic way. However, we unconsciously neglected the national traditional art and culture, and even more neglected the precipitation of thousands of years of Chinese traditional culture and art. Some traditional art features with Chinese flavour have been neglected, so that many students have a weak understanding of traditional Chinese art. This phenomenon has caused a serious impact on our traditional art. If we want to get rid of this impact and realize the inheritance and development of traditional culture, we must inherit the excellent part of traditional culture and innovate the inadequate part of traditional culture to combine inheritance 
and innovation and write a new chapter of traditional culture together. The details of spirit of chinese traditional art please see the figure 1 below.

\begin{tabular}{|c|c|c|}
\hline Тао & $\longrightarrow$ & the Spirit of Chinese Traditional Art \\
\hline Qi & $\longrightarrow$ & the Vitality of Chinese Traditional Art \\
\hline Heart & $\longrightarrow$ & the Subjectivity of Chinese Traditional Art \\
\hline Dance & $\longrightarrow$ & the Music and Dance Spirit of Chinese Traditional \\
\hline & & Art \\
\hline Enlightenment & $\longrightarrow$ & Intuitive Thinking of Chinese Traditional Art Art \\
\hline Harmony & $\rightarrow$ & Dialectical Thinking of Chinese Traditional Art \\
\hline
\end{tabular}

Figure 1 The details of spirit of chinese traditional art

\section{Efforts to Establish Teachers 'Sense of Mission for the Development of Traditional Fine} Arts

Chinese culture is extensive and profound, with rich historical culture, such as Chinese painting, calligraphy, paper-cut and so on. Every art heritage is a rich accumulation of history and culture and is also the most important soft power in human history. The Fine Arts in the traditional culture of the Chinese nation have the characteristics of region and times in different periods. They have vivid historical expressiveness and are widely recognized and praised by the people of the world. They have become the common cultural nutrition of the people of the world. As Chinese, we have an inescapable responsibility to inherit and develop Chinese traditional culture. Therefore, we should strengthen the propaganda and guidance of Chinese traditional art, so that the traditional culture and art of the Chinese nation can be inherited and developed in the new era. If teachers do not grasp the traditional art in place, and do not recognize the fundamental level of traditional culture learning, in the process of teaching, we cannot achieve the inheritance and development of traditional culture and art. This requires each art teacher to shoulder his own mission, constantly strengthen the traditional culture of learning, while creating a good art environment for students in the learning stage. Teachers play an indispensable and important role in the growth of students, and they are also the guides to change students 'learning attitude. Therefore, teachers must shoulder their responsibilities and guide students towards the correct path of traditional art. In the classroom, teachers should impart art knowledge and skills to students, at the same time, increase the cultural background of art, improve students 'understanding of traditional art, guide students to inherit traditional culture and art imperceptibly, and constantly innovate traditional art to carry forward the artistic style of art culture in the new era. Put forward the art culture that belongs to our new era. We should attach importance to the traditional art culture, inherit the tradition, weed out the old and bring forth the new ${ }^{[1]}$.

\section{Develop students 'interest in traditional art}

\subsection{Focus on Classroom Teaching and Pay Attention to the Infiltration of Traditional Art}

Classroom is the main position of teachers 'teaching. Traditional art should be reasonably integrated into the art teaching classroom, so that students can fully understand the inherent 
meaning of traditional art. Therefore, the purpose of preschool education teaching is to enable students to learn art knowledge and skills in the actual art curriculum, at the same time, to learn the humanistic quality behind art, and lay a certain foundation for students to engage in art education in the future. If the students of preschool education have insufficient artistic accomplishment, they cannot meet the needs of current educational development. Therefore, pre-school education students should strive to learn the basic art knowledge, in order to improve their own art knowledge level, we must enhance their own art self-cultivation and understanding. In the process of learning, we should arrange search courses for students, so that students can prepare for the content to be talked about in class in advance. In order to achieve this goal, students can be guided to set up their own study groups to complete. Before teachers begin to teach, they collect materials and pictures to communicate, broaden students 'horizons, guide students to actively engage in classroom learning, cultivate students' interest in art, at the same time, they increase their understanding of art, and at the same time, improve students 'understanding of art culture. Teachers can also tell some inspirational stories of artists before class, so that students are interested in art, and then the introduction of teaching. Through pre-class preparation, classroom communication and dialogue, students have a certain understanding of the teaching content, classroom interaction will become more fun, avoiding the embarrassing atmosphere of traditional classroom teachers and students only listen to the lecture. Through different forms of teaching, students learn not only art skills, skills, but also a sublimation of mood. Continuous cultivation of students 'interest in traditional Chinese art, students' understanding of the long historical and cultural background and excellent historical and cultural traditions, is a topic of special concern to the current art community, especially today, traditional culture is gradually replaced by some new technologies. Teachers do not properly introduce the background and stories of traditional culture in class but impart basic knowledge of art unilaterally. Students think that they have a thorough understanding of art. In fact, they have not yet a deep understanding of art culture ${ }^{[2]}$. Teachers should recognize the importance of traditional art and culture to the development of today's students, and it is also a powerful tool to enhance students 'sense of national identity. In the course of daily teaching, teachers should enhance students 'understanding of traditional art, tell students about the cultural background and historical stories of art, and let students experience the joy of art.

\subsection{Increasing Students 'Traditional Art Training}

At the present stage, the school has launched various courses such as Chinese painting, calligraphy and characteristic handicraft according to the characteristics of art education. The setting of these courses has increased the traditional art courses of art curriculum resources and strengthened the teaching of traditional culture on campus. For example, in the course of Chinese painting, teachers can start from celebrities of calligraphy and painting in their respective hometown and regularly go to the art gallery to watch the exhibition of calligraphy and painting, which makes students feel proud of the excellent works of calligraphers and painters, and at the same time stimulates their strong interest in traditional art in painting. For example, clay sculpture courses are set up in conjunction with local art, and are the artistic resources produced in conjunction with local people's lives. Schools should regularly organize students to participate in traditional art and culture activities, so that students can learn knowledge that they cannot learn in textbooks, and close to students 'life and psychology. Students can choose their own courses according to their favourite subjects, which is conducive to the cultivation of students 'interests and can also rapidly enhance students' awareness of traditional cultural literacy. Through the above ways, while enhancing the penetration of traditional art culture, it is vital for students to strengthen traditional art training. Students should not only learn basic art knowledge, but also be able to exercise their own art skills 
in traditional art training ${ }^{[3]}$. Traditional art training is varied. Teachers can set up projects of traditional art for students according to their learning objectives at different stages, so that students can participate in them and feel the unique charm of traditional culture training. In the process of traditional art training, students can cooperate with each other and explore art knowledge freely, which not only invisibly enhances students 'understanding of art, but also improves their art literacy.

\section{How to Strengthen the Innovation of Traditional Culture}

\subsection{Solid inheritance and learning}

To strengthen the innovation of traditional culture, we should also strengthen the inheritance of traditional culture. The goal of learning traditional art is to achieve new development and innovation of art and to maximize the potential of students. The premise of innovation is inheritance, which is an important aspect of innovation. Therefore, in the process of learning traditional art teaching, teachers should constantly encourage students to master the basic knowledge of traditional art and dare to practice and innovate. They should learn Chinese painting, calligraphy, paper-cut and other traditional arts in a down-to-earth way, so that students can inherit traditional art while continually learning traditional art and experiencing traditional art creation. Some rich contents in the process enable students to truly understand the excellent cultural connotation of traditional art. Inheritance of traditional art is an urgent task in today's social and educational circles, and it is also a mission that contemporary students must achieve ${ }^{[4]}$. The development of traditional culture has been preserved in a long history and has far-reaching historical significance. Students 'inheritance of traditional culture is in line with the current trend of social development. At the same time, in the process of inheriting traditional culture, students can also develop their own wisdom and enhance their understanding of traditional culture.

\subsection{Encouraging the Integration of Innovation}

Students 'impression of traditional art is generally old, not cool colour and shape, but traditional black and white. In view of this situation, if there is no strong persuasion, it is difficult to persuade students to learn traditional art. Therefore, in the traditional art classroom appreciation class, let students understand the charm of traditional Chinese culture elements, at the same time, students should discover the application of traditional culture and art in life. Through the observation of the surrounding life, students are taught to realize that Chinese elements exist in people's real life. For example, the traditional cultural symbol seal, which is used as the design of the emblem of the Beijing Olympic Games, reflects the elements of traditional Chinese culture and is a great innovation in the design history of the Olympic emblem. Therefore, many Chinese people are proud of it. Many Chinese elements are widely used in the field of design. Designers combine traditional elements with modern innovative ideas to innovate traditional elements, which are full of the sense of the times and the sense of the nation ${ }^{[5]}$. Innovation is the eternal theme of the new era. The era is developing and must be innovated. With the spirit of innovation, we can make our country more prosperous and stronger. Students in the new era should not only inherit traditional culture, but also innovate traditional culture, deepen their understanding of traditional culture and improve their literacy about traditional culture.

\section{Conclusion}

The development of traditional art is a long-term process, but also shows a unique charm. The 
development of traditional culture is a process of weeding through the old to bring forth the new and innovating constantly. Inheritance and innovation must be combined. Teachers should treat the advantages and disadvantages of traditional art dialectically, absorb the essence of traditional art rationally, and remove the unreasonable aspects of traditional art. Teachers must have solid traditional art skills, be able to dare to break through and innovate traditional concepts in order to adapt to the pursuit of traditional culture and aesthetic art in contemporary society, so as to enable students to better grasp traditional art, understand the rich connotation and culture of traditional art, and constantly innovate traditional art, so as to enable students to In the process of preschool education, we really learn the nutrition brought by traditional art in fine arts. With the development of traditional art today, it has its own charm. Many experts and scholars are constantly exploring the inherent meaning of traditional art and culture. Therefore, the students of preschool education should grasp the profound connotation of traditional art and understand that traditional culture is an indispensable part of people's daily life. Teachers' understanding of traditional culture should not stagnate. They should keep pace with the development of the times, realize the importance of traditional art and teach students the art culture based on traditional art.

\section{References}

[1] Fang Liang, Zhang Yuxin and Jiang Wei. Study on Contemporary Context and Image Performance of Heilongjiang Watercolor Painting [J]. Art Education, 2018 (11): 134-135.

[2] Wang Xiaotong. Research on the thinking and methods of traditional art in contemporary art education [J]. Chinese Fine Arts, 2017 (06): 121-123.

[3] Wang Xiaotong. New teaching ideas of traditional painting art intervening in contemporary art education [J]. Art, 2016 (06): 140-141.

[4] Zhong Lei. Inheritance and Application of Traditional Folk Art in Contemporary Art Teaching [J]. Drama House, 2016 (08): 166.

[5] Zhang Hongwei. Practical Significance of Traditional Culture and Local Elements in Oil Painting Teaching [J]. Research on Art Education, 2016 (01): $142+144$. 